\title{
COM A PALAVRA, UMA MULHER: O FEMINISMO E AS LIGAÇÕES PERIGOSAS ${ }^{1}$
}

\section{THE VOICE OF A WOMAN: FEMINISM AND DANGEROUS LIAISONS}

\author{
Philio Generino TERZAKIS ${ }^{2}$
}

\begin{abstract}
Resumo: As ligações perigosas: um romance feminista avant la lettre? É essa pergunta que nos guia neste artigo, no qual nos apoiamos nas reflexões teóricas de Gérard Genette e de autores especializados no romance epistolar e na obra de Choderlos de Laclos. Nesse estudo, privilegiamos a categoria do ponto de vista e o estudo do romance epistolar e da personagem da Marquesa de Merteuil, um tipo de Medeia do Século das Luzes que, embora viúva e sem filhos para assassinar, não hesita em ir até as últimas consequências para viver/sobreviver em uma sociedade dominada pelos homens. Ao dar voz a essa personagem, o escritor francês, que também era um ferrenho defensor da liberdade da mulher, traça um panorama da situação feminina em uma determinada classe da França do século XVIII. Um panorama ainda mais opressor por se tratar de uma mulher jovem, rica e viúva, mas tolhida em sua liberdade. Com a perversidade nuançada pela exibição de seus motivos, Merteuil logra escapar do papel de vilã e se consagrar como uma personagem complexa e de características feministas, ainda que avant la lettre. Entretanto, adaptado inúmeras vezes para o cinema e a TV, o romance de Laclos se transforma e o que nos é mostrado é uma Merteuil vilã, com a perda de todos os seus questionamentos a respeito da situação da mulher. Uma releitura desse romance pode, portanto, evidenciar as regras morais anacrônicas às quais ainda hoje a mulher é submetida.
\end{abstract}

Palavras-chave: As ligações perigosas. Choderlos de Laclos. Feminismo. Romance epistolar. Ponto de vista.

\begin{abstract}
Dangerous liaisons: a feminist novel avant la lettre? It is this question that guides us in this article, in which we rely on the Gerard Genette's theoretical reflections and authors specialized in the epistolary novel and in the Choderlos de Laclos' work. In this study, we privilege the category from the point of view and the study of the epistolary novel and the character of the Marquise de Merteuil, a type of Medea of the Age of Enlightenment who, although widowed and without children to assassinate, does not hesitate to go to the final consequences to live / survive in a society dominated by men. In giving voice to this character, the French writer, who was also a staunch defender of women's freedom, traces a panorama of the feminine situation in a certain class of the 18th-century in France. An even more oppressive prospect for being a young woman, rich and widowed, but stuck in her freedom. With the perversity nuanced by the display of its motives, Merteuil manages to escape from the role of villain and to consecrate herself as a complex character and of feminist characteristics, although avant la lettre. However, adapted numerous times to the cinema and TV, Laclos' novel is transformed and what is shown to us is a villainous Merteuil, with the loss of all his questions about the situation of the woman. Thus, a rereading of this novel may evidence the anachronistic moral rules to which the woman is still subjected.
\end{abstract}

Keywords: Dangerous liaisons. Choderlos de Laclos. Feminism. Epistolary novel. Point of view.

\footnotetext{
${ }^{1}$ Este artigo é um recorte da tese de doutorado "As ligações perigosas na literatura e no cinema: ponto de vista e construção de sentidos”, defendida pela autora em 2013, no Programa de Pós-Graduação em Letras da Universidade Federal da Paraíba.

${ }^{2}$ Doutora em Letras pela Universidade Federal da Paraíba. Professora do Departamento de Letras Estrangeiras Modernas da Universidade Federal da Paraíba (UFPB). E-mail: <philiogt@ gmail.com>.
} 


\section{Introdução}

Uma mulher com um plano perverso. Um cúmplice tão perverso quanto ela. Uma jovem casada e virtuosa, mas apaixonada. Um casal de adolescentes apaixonado, mas inexperiente. Ingredientes de um dos maiores romances franceses e mundiais: As ligações perigosas, obra única do francês Choderlos de Laclos, publicado em 1782 - sete anos antes da Revolução Francesa, portanto. Exaustivamente adaptado para o cinema e para a TV (a Rede Globo transformou o romance em minissérie em 2016), As ligações parece corresponder ao desejo de seu autor: ecoar na Terra mesmo depois de seu desaparecimento ${ }^{3}$.

No centro da intriga, uma mulher: a Marquesa de Merteuil, cujo status na obra varia de vilã a feminista avant la lettre, em decorrência da sua complexidade como personagem, construída graças à forma e ao conteúdo do romance. Seria As ligações perigosas um romance "feminista" ou de temática feminista? Essa é a discussão que pretendemos estabelecer neste artigo, a partir de considerações sobre a forma do romance epistolar, a construção do foco narrativo e a caracterização da personagem da Marquesa de Merteuil.

\section{Um romance feminista?}

Militar de carreira e pai de família devotado, Choderlos de Laclos (1741-1803) frequentava a nobreza do tempo, conhecendo profundamente seus hábitos. Dedicou-se à atividade de escritor por não conseguir galgar altos postos na vida militar, em decorrência de sua origem burguesa - os melhores lugares eram reservados para os nobres. Conhecido pelo caráter frio e metódico, Laclos escreveu poemas e textos diversos, mas é considerado um escritor de uma obra só. Seu único livro publicado, lançado em 1782, foi um sucesso, mas provocou escândalo e só foi reabilitado pela Academia no século XX.

A história do romance se passa na França do século XVIII, em meio à aristocracia. Gira em torno da vingança da Marquesa de Merteuil e do Visconde de Valmont contra o Conde de Gercourt, que teria abandonado a libertina para se casar com a jovem Cécile de Volanges - esta apaixonada pelo Cavaleiro Danceny. Corromper Cécile antes do casamento é a missão de Valmont que, ao mesmo tempo, seduz Madame de Tourvel, mulher casada e virtuosa. A descoberta do plano provoca uma tragédia. Tourvel adoece e morre. Cécile volta para o

\footnotetext{
${ }^{3}$ Durante a escrita de seu romance, Laclos teria dito ao conde de Tilly, com quem conversou algumas vezes: "Eu decidi fazer uma obra extraordinária, que faça barulho e que ecoe ainda na terra depois da minha morte". A frase foi incluída nas memórias do conde e é frequentemente citada por estudiosos de As ligações, tais como Roger Vailland (1953, p. 8) e Michel Delon (1990, p. 17).
} 
convento. Valmont e Danceny se batem em duelo, resultando na morte do primeiro. Desfigurada pela varíola e falida, Merteuil foge para um destino ignorado.

Alguns estudiosos da obra de Laclos, como Jean-Luc Seylaz (1998) resistem à ideia de considerar As ligações como um livro feminista ou de temática predominantemente feminista - até porque esse termo nem existia na época, embora as reivindicações femininas já fossem uma realidade há tempos ${ }^{4}$. Nesse sentido, ele afirma:

[...] a etiqueta de "romance feminista" é realmente a última, acreditamos, que vem ao espírito do leitor desprevenido de As ligações [...] A atitude de Valmont e de Madame de Merteuil em relação àqueles que não são instrumentos de seus prazeres, sua falta de solidariedade para com os do seu próprio sexo [...] sua cumplicidade de carrascos diante de suas vítimas dos dois sexos, todos esses sentimentos colocam outros problemas diferentes do da desigualdade social do homem e da mulher e se situam completamente em outro plano [...] (SEYLAZ, 1998, p. 90-91).

Entretanto, não se pode negar a crítica contida no romance a respeito da situação da mulher no século XVIII - ela é particularmente visível na Carta 81, de Madame de Merteuil, como veremos mais adiante, mas pode ser facilmente observada por meio do estudo de qualquer uma das três principais personagens femininas: Merteuil, Tourvel e Cécile - e até mesmo Rosemonde (tia de Valmont) e Volanges (mãe de Cécile). A título de exemplo, fica claro que a educação recebida por Cécile, encerrada em um convento por vários anos, foi a principal razão de sua vulnerabilidade diante das artimanhas do visconde.

O contexto histórico da época também legitima nossa interpretação. Publicado sete anos antes da Revolução Francesa, o romance é um autêntico representante do Século das Luzes. A literatura libertina ou sobre libertinos - na qual podemos incluir As ligações - conviveu harmoniosamente com as concepções filosóficas do século XVIII, de modo complementar, em "uma divisão de trabalho pela qual os filósofos se encarregavam de minar os alicerces políticos do ancien régime, e os autores libertinos seus alicerces morais" (ROUANET, 1990, p. 168). Esses escritores partilhavam dos ideais morais, religiosos, políticos e sociais da Ilustração, divulgando-os em ambientes aristocráticos e burgueses. Eles não só se inspiram nos filósofos, mas os citam diretamente. Segundo Sérgio Paulo Rouanet (1990, p. 167), “o libertino é um homem dissoluto que consagra sua vida ao prazer, principalmente o prazer erótico". É exatamente essa vida de prazer que será criticada nos romances:

\footnotetext{
${ }^{4}$ Evidentemente estamos conscientes de que o movimento feminista e o próprio termo feminismo datam do século XIX, mas utilizamos a palavra no sentido do sentimento de reivindicação de um lugar mais justo para a mulher, na sociedade - sentimento este muito anterior às lutas que se intensificaram no século XX e já presente em uma obra como Medeia, peça do grego Eurípedes, datando do séc. V a.C.
} 
O público dessas novelas era em parte composto dos próprios nobres, mas elas eram amplamente difundidas pela burguesia culta. Não há dúvida de que essas novelas contribuíram, por essa via, para completar a denúncia dessa mesma sociedade que os filósofos realizavam por outros meios (ROUANET, 1990, p. 171).

Os escritores libertinos criticavam a devassidão dos religiosos; exaltavam a moralidade secular, que não tem fundamento na religião, mas na própria natureza; condenavam o despotismo; por fim, reforçavam o igualitarismo da Ilustração, não apenas a igualdade econômica, mas a igualdade entre os sexos. Tanto os filósofos como os escritores libertinos eram, de certo modo, "feministas", particularmente no que diz respeito à liberação sexual da mulher. Ora, Laclos chegou a dar início a um tratado onde defendia uma nova educação para as mulheres (LACLOS, 2007). Nessa obra, intitulada Das mulheres e de sua educação, o autor de As ligações chega a convocá-las para uma revolução:

Ó mulheres! Aproximem-se e venham me ouvir. Que sua curiosidade, dirigida pelo
menos uma vez para questões úteis, contemple as vantagens que a natureza lhes
concedeu e que a sociedade lhes tomou. Venham aprender como, nascidas
companheiras do homem, vocês se tornaram suas escravas; como, caídas nesse estado
abjeto, vocês vieram a se acomodar, a olhá-lo como seu estado natural [...] Aprendam
que só podemos sair da escravidão por meio de uma grande revolução (LACLOS,
2007, p. 390-391).

Dessa maneira, a nosso ver, a análise de Seylaz (1998) é um tanto quanto limitante. Negar o aspecto feminista do romance apenas porque a marquesa não é solidária às outras personagens femininas é empobrecer não apenas o feminismo, mas a literatura e o próprio romance. O que faz de Merteuil uma personagem feminista por excelência é sua própria essência, sua revolta legítima contra uma sociedade que escraviza as mulheres; sua busca por meios de viver integralmente, sem ser massacrada pelo mundo dos homens - ainda que, nessa busca, ela se volte contra seu próprio sexo. E fica evidente a posição feminista do próprio autor, como afirma Roger Vailland (1953, p. 27), para quem Laclos “[...] se mostra, em relação ao seu século, como o mais audaz defensor da igualdade do homem e da mulher [...]".

Certamente As ligações não é um romance feminista ou mesmo de temática predominantemente feminista. Nem poderia ser. Entretanto, o romance apresenta traços importantes de reivindicação nesse sentido, o que justificaria por si só um estudo da obra enquanto tal. A desigualdade entre homens e mulheres seria uma parte desse mal que, para Laclos, é social e que constitui a temática principal de As ligações. Inspirado por Jean-Jacques Rousseau (1712-1778), cujo romance A nova Heloísa (1761) é um de seus preferidos, Laclos também acha que esse mal social pode ser combatido pela educação. 


\section{Voz e romance epistolar}

A forma do romance epistolar permite à Marquesa de Merteuil não apenas ganhar voz, mas dar voz à mulher - ou a um tipo de mulher - do século XVIII, ainda que por meio de um autor masculino. Por essa razão, vamos nos deter aqui no estudo dessa forma literária que atinge seu auge no século XVIII, embora já fosse conhecida desde a Antiguidade (ROUSSET, 1962). A literatura epistolar é, portanto, contemporânea da constituição do romance moderno, entre o final do século XVII e o início do século XIX, e inclui entre seus autores nomes como: Richardson, Goethe, Montesquieu, Rousseau, Laclos e Balzac.

A moda do romance epistolar foi uma consequência da cultura da carta, que ganhou um novo impulso com o surgimento dos primeiros serviços postais, por volta de 1650 (HUMBERT, 2000), e também com a difusão da educação, a atração crescente dos salões literários e uma vida política mais estável. Nesse contexto, correspondências particulares transformaram-se em obras literárias e as cartas ficcionais também passaram a povoar a literatura. Lembremos, entretanto, que romance epistolar, em um sentido estrito, não é carta na narrativa ou narrativa em forma de carta - há graus de epistolaridade. Afirma Calas (2007, p. 23): "Um romance por meio de cartas é um romance no qual a ação se faz pelas cartas e não apenas um romance onde as cartas servem de quadro para a narrativa da ação".

Os romances epistolares também podem ser classificados segundo o número de vozes que colocam em ação, das obras mais simples (voz solista) às mais complexas (múltiplas vozes) (ROUSSET, 1962). As ligações pertence ao último tipo, a obra sinfônica, com a orquestração de mensagens de vários correspondentes, uma invenção do século XVIII, com grande aposta na subjetividade, de acordo com Calas (2007, p. 38), que precisa:

\footnotetext{
A obra de Laclos propõe o esquema de troca de cartas mais complexo que existe, pois cada correspondente principal entretém várias correspondências, cada personagem está em relação com pelo menos três outros [...] A complexidade das fórmulas, a imbricação das redes atingem nesse romance seu paroxismo [...] Armadilhas são armadas em permanência no deciframento do sentido: ordem das cartas, cartas ocultas, cartas roubadas, carta anônima, carta rasgada, carta ditada por um terceiro.
}

O romance por cartas foi uma das reações às críticas sofridas pelo romance no século XVIII, quando o gênero foi acusado de estragar o gosto, corromper os hábitos e apresentar narrativas inverossímeis. Criticado e perseguido, o romance torna-se mais realista para fugir das críticas. Daí o hábito de os escritores afirmarem que suas histórias tinham fontes reais e escreverem prefácios realçando o valor moral de suas obras (MAY, 1963). A regra de Horácio 
(2005, p. 65) parecia ser seguida à risca: “Os poetas desejam ou ser úteis, ou deleitar, ou dizer coisas ao mesmo tempo agradáveis e proveitosas para a vida".

Narrativa na primeira pessoa, apagamento do narrador onisciente, utilização predominante do tempo presente, aproximação entre narrado e narração e variação dos estilos dos correspondentes (no caso dos romances sinfônicos). Essas são as principais características que costumam acompanhar esse subgênero literário. No caso da obra sinfônica, é construído um ponto de vista peculiar: a visão pluriocular (CALAS, 2007, p. 100).

A questão da narrativa em primeira pessoa está no cerne da definição. Calas (2007, p. 9) afirma: "O romance epistolar se define por essa possibilidade extraordinária que ele oferece de situar o leitor no coração mesmo de uma consciência que se descobre escrevendo diretamente, de maneira transparente, no tumulto de suas paixões". As cartas escritas na primeira pessoa costumam levar a uma utilização preponderante do tempo presente, uma vez que os personagens escrevem sua vida quase ao mesmo tempo em que a vivem, tornando o leitor contemporâneo da ação. Além disso, o romance epistolar com mais de um personagem tende a marcar as diferenças de estilos entre correspondentes e a utilizar essa variação como uma estratégia de caracterização de cada personagem (policromia).

Essas cinco características tendem a dotar o romance epistolar sinfônico de dois traços complementares: a exposição variada e subjetiva dos acontecimentos (visão pluriocular) e uma maior exigência de interpretação por parte do leitor. Dessa forma, diferentemente de uma narrativa com narrador onisciente, vários personagens assumem o lugar do narrador, do eu da enunciação. Para Émile Benveniste (2000, p. 259), a subjetividade na linguagem é justamente a capacidade do locutor de se colocar como sujeito da enunciação: “É na e através da linguagem que o homem se constitui como sujeito; porque apenas a linguagem funda na realidade, na sua realidade que é aquela do ser, o conceito de "ego"”. A presença do $e u$ pressupõe a existência de um $t u$; esse $t u$, por sua vez, também pode tornar-se um $e u$. É assim que acontece a comunicação. Esse $e u$ não se refere a um conceito ou indivíduo determinado; ele é uma instância do discurso e só tem, portanto, referência atual. Para Calas, um único narrador, ainda que se exprimisse na primeira pessoa, nunca poderia criar os efeitos poderosos da forma epistolar polifônica. Partindo da mesma perspectiva, Rousset (1962, p. 85) afirma:

Por trás dessas cartas, há todos esses personagens diversos, que não apenas têm cada um sua personalidade e seu estilo, mas ainda sua maneira de compreender e de explicar, a si mesmo, sua situação; a ótica de cada um varia constantemente, primeiro, de acordo com essa personalidade, depois, segundo o lugar que ele ocupa no grupo e de acordo com o momento no qual ele escreve. A multiplicação dos personagens leva 
à multiplicidade de pontos de vista e de iluminação; essa diversidade de óticas é uma marca essencial dos romances desse tipo.

Isso é particularmente verdade no caso de As ligações, que não oferece um final fechado ou a explicação definitiva para as ações de seus personagens. As cartas terminam por oferecer uma visão subjetiva e limitada dos acontecimentos - mesmo porque nem sempre o próprio correspondente conhece sua verdade profunda - e/ou várias visões sobre um mesmo evento. Assim, torna-se difícil congelar esse ou aquele personagem no papel de vilão ou mocinho. Onde está a verdade? Ou as verdades? Calas (2007, p. 100) observa:

O leitor tem uma margem maior para apreciar mais justamente o acontecimento e
aqueles que fazem a narrativa dele. Ele pode avaliar a justeza de vista de uns e verificar
a pertinência da descrição ou do julgamento dos outros, corrigir certas interpretações
falsas e construir enfim sua própria impressão. O romance polifônico oferece uma
visão pluriocular dos acontecimentos. O leitor é então constituído pela soma das
visões subjetivas e parciais de cada um.

Ora, o ponto de vista de uma narrativa faz com que o leitor acompanhe e se identifique com o fio condutor da narração - sejam eles narradores e/ou personagens. A mudança do fio condutor é suficiente para alterar consideravelmente a história, como bem observou Boris Tomachevsky (1973). Ou seja, a constituição de um narrador ou de um personagem como eu da narrativa tem o poder de criar no leitor a identificação com esse sujeito da enunciação. Esse é um efeito proporcionado pela construção do ponto de vista. No caso das narrativas com múltiplos pontos de vista, como é o caso do romance epistolar polifônico, o leitor é levado a construir vários eus, de acordo com a quantidade de personagens que tomam a palavra e se transformam em fios condutores da narração. Ele também é obrigado a, posteriormente, assumir o papel do tu, quando a tarefa da narração passa para os outros personagens. É esse jogo que pode obrigar o leitor a assumir um papel mais ativo na interpretação da obra, uma vez que os papéis da enunciação não estão definidos por um narrador onisciente.

É o que acontece em As ligações, que é constituído por 175 cartas, divididas em quatro parte, com 50, 37, 37 e 51 correspondências, respectivamente. A voz da Marquesa de Merteuil é a segunda mais presente no romance, com 27 cartas enviadas e 42, recebidas (69 cartas ao todo). Ela perde apenas para o Visconde de Valmont, que envia 51 cartas e recebe 38 (um total de 89 cartas). Na tabela abaixo, podemos ver os principais personagens e sua contribuição para a correspondência da intriga apresentada por Laclos. 
Tabela 1 - Principais personagens e sua contribuição para a correspondência da intriga apresentada por Laclos

\begin{tabular}{l|c|c}
\hline \multicolumn{1}{c|}{ PERSONAGEM } & CARTAS ENVIADAS & CARTAS RECEBIDAS \\
\hline Visconde de Valmont & 51 & 38 \\
\hline Marquesa de Merteuil & 27 & 42 \\
\hline Madame de Tourvel & 24 & 20 \\
\hline Cécile de Volanges & 25 & 13 \\
\hline Cavaleiro Danceny & 19 & 15 \\
\hline Madame de Rosemonde & 2 & 22 \\
\hline Madame de Volanges & 13 & 10 \\
\hline Outros & 7 & 15 \\
\hline
\end{tabular}

Fonte: Este quadro é de nossa autoria.

Se Merteuil não se transforma em vilã e torna-se capaz de ecoar os sofrimentos e anseios de um tipo de mulher do século XVIII, é em grande parte pela voz que ela tem o poder de utilizar no romance epistolar. Essa forma contribui para dividir o peso do mal entre os personagens, uma vez que a correspondência possibilita o conhecimento da subjetividade dos vilões, mostrando suas motivações e fraquezas, ao mesmo tempo em que evidencia o lado não tão inocente de Tourvel, Cécile e Danceny, com suas próprias falhas e paixões, que contribuíram igualmente para a tragédia final. André Malraux (2007, p. 7), cuja análise do romance é anterior à de Seylaz e lhe serviu de inspiração, ressalta, por exemplo, a predisposição das vítimas ao ataque do visconde e da marquesa:

As ligações são a narrativa de uma intriga [...] Intrigar tende sempre a "fazer acreditar" algo a alguém; toda intriga é uma arquitetura de mentiras; crer na intriga é acreditar de início que podemos agir sobre os homens - por suas paixões, que são suas fraquezas. Há subjacente uma visão do homem que encontrou algumas expressões literárias consideráveis [...] "conhecer os homens para agir sobre eles".

No caso de Valmont e Merteuil, o mal explícito é equilibrado com argumentos que mostram um lado positivo dessas personagens. Sua perversidade já está exposta desde as primeiras páginas (Carta 2, para Merteuil, e Carta 4, para Valmont), nas quais eles revelam seus planos de corrupção de Cécile e Tourvel. Anunciando seu plano de "amor" e "vingança" e pedindo a colaboração do visconde, a marquesa afirma que a esperança de se vingar acalma sua alma. Sobre Gercourt e sua preferência pelas mulheres loiras e educadas em um convento, ela se expressa ironicamente da maneira seguinte:

Efetivamente, eu aposto que, apesar das 60 mil libras de renda da pequena Volanges [Cécile], ele não faria esse casamento se ela fosse morena ou se ela não tivesse estado em um convento. Vamos provar que ele não passa de um tolo [...] Como nós nos divertiríamos escutando-o se vangloriar no dia seguinte [ao casamento]! [...] além do mais, se você formar essa mocinha, Gercourt se tornará certamente a piada de Paris (LACLOS, 2007, p. 36-7). 
Entretanto, ao longo do romance, veremos Merteuil expor muito mais do que seus planos maquiavélicos de vingança: a mágoa de Gercourt, o ressentimento social, uma possível paixão por Valmont, a necessidade de se defender de Prévan. Enfim, Laclos não nos mostra uma vilã simplista, cujo mal estaria enraizado em sua essência, e sim uma mulher vulnerável, tornada forte pela necessidade de sobreviver em uma sociedade machista. E não apenas sobreviver, mas viver, usufruindo do prazer das relações amorosas. E, para isso, tendo que recorrer a estratagemas permitindo a manutenção de sua boa reputação e mesmo de sua situação econômica. Não podemos esquecer que, ao final do romance, a perda de sua reputação contribui para a derrota em um processo que a priva de sua fortuna.

\section{As ligações e seu ponto de vista}

A relação próxima entre romance epistolar e ponto de vista narrativo nos leva a explorar essa categoria narrativa e estabelecer sua relação com a caracterização da Marquesa de Merteuil, como personagem de aspectos feministas.

Diante da multiplicidade de teorias sobre o ponto de vista (também conhecido como visão, perspectiva, foco narrativo, etc.), vamos nos ater à definição de Gérard Genette (2007), de quem também tomamos emprestada a tipologia sobre o assunto. No estudo dessa categoria, Genette separa o modo da voz. O ponto de vista é, segundo ele, um dos dois modos de regulação da informação em uma narrativa (quem vê) - o segundo modo é a distância, que tem a ver com a quantidade de informação transmitida (quem fala). Em um estudo posterior, Genette substitui as questões quem vê? e quem fala? por qual é a origem da percepção?, por considerar que essa palavra exprime melhor as diversas facetas que pode assumir a filtragem da narração tanto pelo narrador, quanto pelos personagens. Ele mantém, todavia, a distinção entre modo e voz - cuja relação determina a chamada situação narrativa.

Genette propõe, então, o termo focalização. Para ele, só existem dois pontos de vista: interior (subjetivo) ou exterior (objetivo), que podem se manifestar por meio de quatro vozes: o herói-narrador, a testemunha-narradora, o narrador onisciente e o narrador não onisciente. Apresenta, em seguida, a seguinte tipologia: narrativa não focalizada ou de focalização zero (a narrativa clássica, em geral); narrativa de focalização interna (fixa, variável ou múltipla); e narrativa de focalização externa. No primeiro caso, o narrador (onisciente) sabe e diz mais que o personagem; no segundo, ele diz apenas o que sabe o personagem; no terceiro, o narrador diz menos do que sabe o personagem. 
Determinar o(s) tipo(s) de focalização existente(s) em As ligações, entretanto, não é tarefa fácil, pois há uma flutuação da focalização ao longo da narrativa ${ }^{5}$. No nível da troca das cartas, podemos falar em uma combinação entre a focalização interna múltipla e a focalização externa. Ou seja, ao mesmo tempo em que os narradores-personagens possuem, evidentemente, a mesma quantidade de informações sobre si e se revezam no ato de narrar (focalização interna múltipla), o suspense e a ambiguidade são criados porque as cartas não dizem tudo e os narradorespersonagens não sabem tudo uns sobre os outros (focalização externa) - particularmente no que diz respeito aos personagens secundários: Tourvel, Danceny, Cécile, Madame de Volanges, Madame de Rosemonde, etc.

Já Valmont e Merteuil se transformam em narradores oniscientes (focalização zero) de seus correspondentes, seja por inteligência e experiência, seja por meios ilícitos. Valmont intercepta as cartas destinadas a Tourvel (Carta 44) e contrata um espião para vigiar seus movimentos quando ela segue para Paris (Carta 107). A marquesa, por sua vez, torna-se confidente de Cécile (Carta 27) e utiliza seus segredos contra a própria jovem; ela também é confidente de Madame de Volanges, como revela na Carta 2. Mas qual a verdade completa sobre ambos? Ela não é acessível nem ao final da obra.

Assim, o leitor não tem acesso a um ponto de vista onisciente e tem que preencher as lacunas de informação deixadas pelos narradores. Essa complexa estrutura narrativa oferece o acesso a pontos de vista múltiplos e, logo, a uma maior ou menor subjetividade dos personagens. O efeito final dessa estrutura é paradoxal. Por um lado, temos acesso às contradições de caráter dos cinco personagens principais, impedindo a fixação de uns e de outros no papel de bom ou mau. Por outro lado, as cartas, por mais íntimas que sejam, não contam tudo - sobretudo a respeito dos dois protagonistas. Valmont se deixou matar por Danceny? Ele amava realmente Tourvel? Merteuil amava o visconde? Os castigos recebidos foram o fim de sua vida de libertina?

Assim, graças à complexidade do foco narrativo, a personagem de Merteuil não é congelada no papel de vilã, tornando-se uma voz feminina e, por que não, feminista? - ainda que avant la lettre - na obra de Laclos. Com a exposição da sua subjetividade, por meio de suas próprias palavras, o leitor pode verificar que, se há maldade nos seus atos, ela não é gratuita, como no caso dos vilões tradicionais.

Entramos, assim, no terreno da motivação, que é um fator-chave para garantir a adesão do leitor a um personagem. Em As ligações, a ambiguidade das motivações dos personagens

\footnotetext{
${ }^{5}$ Por sinal, essa flutuação da focalização é uma característica da maior parte das narrativas, de acordo com Gérard Genette (2007). Geralmente podemos falar apenas de uma focalização predominante.
} 
para suas ações, reconhecida por vários estudiosos da obra, exige uma participação mais ativa do leitor, para sua interpretação. Afirma René Pomeau (1993, p. 142): "Suprimindo, aparentemente, o romancista onisciente, o romance por cartas institui um leitor onisciente, capaz de interpretar corretamente cada carta, porque ele as lê todas e pode estabelecer comparações”. Henri Coulet (1968, p. 480) ressalta: “[...] como em quase todos os romances por cartas que merecem esse nome, a verdade não está em nenhum personagem, ela está em um lugar onde convergem os diversos fragmentos de verdade e onde se compensam os diversos erros". E Laurent Versini (1998, p. 188): "O leitor, em um romance epistolar, sobretudo polifônico, é sempre encarregado de construir a verdade ou uma verdade a partir de visões fragmentadas e parciais [...]".

Outro fator a garantir a riqueza subjetiva do caráter da marquesa é o desfecho, no qual nenhum dos personagens é poupado da tragédia - nem mesmo as vítimas. Ou seja, o bem não triunfa, pois nenhum dos personagens é perfeito e cai sob o peso das próprias fraquezas: Merteuil e Valmont, o orgulho e a vaidade; Tourvel, Cécile e Danceny, a inexperiência, a ignorância, o autoengano e a própria corrupção. Versini (1998, p. 162) destaca: “[...] trata-se de verdadeiros seres humanos e não de marionetes ao serviço de uma tese". Talvez o final infeliz para os três últimos nem chegue a espantar o leitor. Afinal, ao longo de todo o romance, foi dada a palavra aos sedutores, reforçando sua superioridade, e possivelmente impedindo a simpatia do público com suas presas, como observa Pomeau (1993, p. 130): "Em um romance da sedução, entre o romancista e os sedutores, se estabelece uma colaboração que leva a uma cumplicidade". Além de o bem não triunfar, o mal não é castigado, como bem observou Pomeau: Merteuil e Valmont têm um final trágico não por serem libertinos, mas por terem desrespeitado os próprios princípios, entregando-se aos sentimentos de vaidade, ciúme e orgulho e perdendo a frieza de jogadores que mantinham até então. Talvez movidos pela paixão - Merteuil por Valmont, e este por Tourvel. De qualquer modo, eles não apenas não se arrependem, como têm o lugar usurpado por outro libertino, Prévan. A libertinagem não é castigada, e a inocência não é recompensada.

Esse desfecho é coerente com a concepção de mal de Laclos e de Rousseau. O mal é social e não pode perder no final do romance, pois a sociedade em questão não mudou. Merteuil e Valmont são o resultado de uma sociedade onde impera a desigualdade, não apenas econômica, mas sexual. As queixas de Merteuil (Carta 81), a respeito do lugar inferior destinado à mulher na sociedade, seriam pertinentes, mas ela teria escolhido a maneira errada de sobreviver, destruindo outros seres humanos, incluindo as representantes de seu próprio sexo. Valmont, como a própria marquesa define na mesma carta, escolhe a comodidade da vida de 
libertino, facilitada pelo seu lugar privilegiado na sociedade, como homem e aristocrata. $\mathrm{O}$ destino de Tourvel e Cécile denuncia a ineficácia da educação recebida pelas mulheres da época, onde havia muita religião e pouca informação. Nem mesmo a inocência da juventude (mal) representada por Cécile e Danceny - escapa à corrupção da sociedade. A educação inadequada é incapaz de corrigir as fraquezas de todos.

Para Jean-Luc Seylaz (1998), As ligações são, antes de tudo, uma "obra de desmistificação", na qual é revelada "a verdadeira natureza do homem e a verdadeira significação desse comportamento" (p. 94). Ele afirma:

[...] o escândalo que o romance provoca, a fascinação que ele exerce, nascem bem menos dos costumes que Laclos estava denunciando, que do que triunfa nesses personagens sem idade e sem pitoresco: o que nós chamamos provisoriamente, para retomar uma expressão de Marcel A. Ruff, o "espírito do mal" (SEYLAZ, 1998, p. 96).

O autor acredita que o livro não apenas conta a história do ponto de vista do mal (Valmont e Merteuil, que são os dois grandes protagonistas do romance), como também derruba crenças fortes da época, como a da inocência da juventude (Cécile e Danceny) e a da força da virtude (Tourvel) - ambas são esmagadas sob a ação do "espírito do mal", que corrompe Cécile e Danceny, destrói Tourvel e, além de tudo, põe um fim à carreira libertina de Valmont e Merteuil. Seylaz explica (1998, p. 92):

Trair o segredo, fazer explodir uma verdade escandalosa, não era revelar o comportamento real dessa sociedade ou publicar suas aventuras (o que vários outros romancistas da época já haviam feito, sem provocar o escândalo que provocou $A s$ ligações). Mas era desnudar a significação profunda de uma atitude, o verdadeiro rosto dos seres e o verdadeiro alcance de seus gestos.

\section{“É preciso vencer ou morrer": a Carta 81}

A exposição das motivações de personagens cruéis pode amenizar essa maldade. É o que acontece com a vilania da marquesa graças principalmente às Cartas 81 e 85 . Na primeira, ela conta sua história, denunciando a frágil situação das mulheres na sociedade da época; na segunda, que não será analisada neste artigo, relata o episódio da sedução de Prévan, um conquistador que pretendia seduzi-la e destruir sua boa reputação. A seu favor, Merteuil tem ainda sua inteligência, superior mesmo à de seu parceiro de libertinagem, o Visconde de Valmont, e sua sensibilidade. É ela que arquiteta os planos de vingança. É ela que enxerga a paixão do visconde por Tourvel, antes mesmo que ele seja capaz de perceber. É ela ainda que 
dá o xeque-mate em Valmont, antes de ser colocada em segundo plano por essa mesma paixão sentida por outra mulher.

A Carta 81, portanto, revela que Merteuil está longe de apresentar uma maldade gratuita, o que acabaria desqualificando ou diminuindo seu valor como voz feminina e porta-voz de um feminismo avant la lettre. Sua crueldade é uma resposta, talvez equivocada, mas uma resposta à própria sociedade, fonte do mal. Essa carta, de uma sinceridade e lucidez espantosas, dignas de uma feminista contemporânea, revela ainda a consciência de Laclos a respeito do lugar da mulher na sociedade. "É preciso vencer ou morrer", conclui a marquesa ao final (LACLOS, 2007, p. 177). É importante ressaltar que Merteuil não escolhe apenas sobreviver, mas realmente viver, usufruindo da vida livre da qual se sente merecedora, ainda que tomando os cuidados necessários para sustentar sua reputação, cuja perda poderia acarretar sua queda não apenas social, mas econômica - o que efetivamente se concretiza no final do romance.

$\mathrm{Na}$ Carta 81, que podemos chamar de sua profession de foi, a Marquesa de Merteuil responde aos conselhos do Visconde de Valmont, que lhe pede para tomar cuidado com as investidas de Prévan. Para o visconde, era provável que, buscando seduzir o libertino, Merteuil não apenas acabasse seduzida, como também visse irremediavelmente manchada sua fama de mulher respeitável. O conselho de Valmont é, portanto, um conselho de amigo. Mas isso não amolece o coração da aristocrata e é considerado antes como uma ofensa. Ela recebe esses conselhos como uma afronta a sua inteligência e experiência:

\begin{abstract}
Ah! Guarde seus conselhos e temores para essas mulheres delirantes que se dizem sentimentais, cuja imaginação exaltada faria pensar que a natureza colocou seus sentidos na cabeça; que, nunca tendo refletido, confundem incessantemente o Amor e o amante; que na sua grande ilusão, aquele com quem elas procuraram o prazer é o seu único depositário; e, verdadeiras supersticiosas, tem pelo sacerdote o respeito e a fé que só é devido à divindade (LACLOS, 2007, p. 170).
\end{abstract}

Nesse ponto, Merteuil resolve então contar sua história a Valmont, que ela considera um inferior, para lhe mostrar que não precisa de sua orientação nem cuidados, pois sabe muito bem se defender sozinha. Lembra que teria desenvolvido suas habilidades arte da sedução e da manutenção das aparências mesmo antes de chegar aos 15 anos de idade. Nascida, segundo ela, para vingar seu sexo e dominar o sexo masculino, declara-se perfeitamente capaz de escapar das armadilhas dos homens, referindo-se a estes como "escravos destronados, tornados seus escravos" (LACLOS, 2007, p. 169). Ainda menina, forçada ao silêncio e à inação, como toda mulher, soube observar os discursos, fingindo distração e imaturidade. Aprendeu a dissimular, a fingir serenidade e alegria, mesmo sentindo dor. Aprendeu igualmente a esconder uma alegria 
inesperada. Seu objetivo: apropriar-se de seu pensamento, a única coisa que ela tinha de seu, uma vez que, como mulher, devia obediência e submissão a sua família e, futuramente, àquele que seria seu marido. Ela explica: “[...] me indignava que pudessem tomá-lo [seu pensamento] ou me surpreender contra a minha vontade" (LACLOS, 2007, p. 171).

Dessa maneira, antes dos 15 anos, afirma, já era tão competente quanto os melhores políticos. Mas ainda se considerava no começo da sua formação, pois queria se instruir no amor. Nesse momento de sua vida, foi casada com o Monsieur de Merteuil, com quem decidiu começar a se educar sexualmente. Sabendo fingir fidelidade, logo desfrutou da total confiança do marido, podendo traí-lo tranquilamente, além de frequentar sua cama. Este logo morreu, deixando-a jovem, rica e viúva. Ela continuou, então, sua educação prática e teórica: "Estudei nossos costumes nos romances; nossas opiniões nos filósofos. Pesquisei mesmo o que os moralistas mais severos exigiam de nós, me assegurando, assim, do que podemos fazer, do que devemos pensar e do que era necessário parecer" (LACLOS, 2007, p. 173). Armas essenciais em um mundo no qual as relações são mais difíceis para as mulheres que para os homens, que têm o poder de iniciar e encerrar ligações - a mulher pode apenas agradecer diante de um “abandono humilhante” (LACLOS, 2007, p. 169), no qual sua reputação foi poupada.

Aprendizado concluído, ela afirma: "Eu posso dizer que sou minha obra" (LACLOS, 2007, p. 170). Seu maior objetivo: fazer tudo o que tinha vontade sem perder a boa reputação, o que lhe levaria a um ostracismo social. Suas armas: descobrir segredos importantes (para garantir uma chantagem em caso de necessidade), fazer-se largar pelos homens (para não despertar sua vingança) ou simplesmente negar tudo (no que era favorecida pela sua boa reputação). Regra básica: nunca escrever cartas de amor, pois o amante atual é o futuro inimigo. De resto, a marquesa realmente não é indulgente com o próprio sexo, mas apenas porque considera as outras mulheres ignorantes, imprudentes, fracas. Não por serem mulheres. Apenas por reconhecer que seu procedimento é único. Ela escolhera vencer. Não mudando a sociedade, o que, antes da Revolução Francesa, ainda não passava de uma possibilidade na mente dos mais revolucionários, mas mudando a si mesma.

\section{Considerações finais}

Neste artigo, buscamos enfatizar o romance As ligações perigosas, do escritor francês Choderlos de Laclos, publicado em 1782, como uma obra com traços feministas, ainda que avant la lettre, a partir da personagem da Marquesa de Merteuil, uma das protagonistas da história. Ressaltamos que, embora tenha sido escrito por um homem do século XVIII, esse 
romance, que é um dos mais importantes da literatura mundial, dá voz a uma mulher e a suas reivindicações na sociedade da época, não apenas por meio da forma do romance epistolar, como da categoria narrativa do ponto de vista e da própria construção da personagem da aristocrata libertina, tentando viver/sobreviver de acordo com suas necessidades e desejos, o que não era permitido às mulheres do período, ainda que ricas e livres.

A importância da releitura desse romance torna-se ainda mais visível quando constatamos que a Marquesa de Merteuil é transformada em uma simples vilã em praticamente todas as adaptações para o cinema e a TV da obra de Laclos (TERZAKIS, 2013). Esse não é o assunto deste artigo, mas é importante mencionar esse fato que indica que regras morais às quais são submetidas as mulheres há centenas de anos - isso levando em consideração apenas a cultura cristã - não foram abolidas nos séculos XX e XXI, embora já fossem questionadas por um escritor do Século das Luzes. Dessa maneira, a investigação de antigas narrativas apresenta-se como um estudo sempre atual para que possamos construir um olhar cada vez mais atento à realidade que vivemos na contemporaneidade.

Estamos conscientes de que a crítica feminista, cujo início se localiza nos anos 70, vem muito acertadamente focando na (re)descoberta de escritos literários produzidos por mulheres, em contraposição a uma história da literatura que, até então, havia privilegiado o autor ocidental, homem, branco e originário de classes mais abastadas (ZOLIN, 2009). Essa iniciativa fez aparecer paulatinamente uma série de escritoras que trabalharam intensamente ao longo de nossa História. Pois a verdade é que as mulheres nunca deixaram de escrever, embora sua produção não tenha sido tão valorizada quanto a masculina, sendo uma prova disso o trabalho da poetisa grega Safo (séculos VII-VI a.C.). Estamos assim, desde o século XX, trazendo à tona essas vozes silenciadas durante tanto tempo.

Entretanto, isso obviamente não invalida o trabalho de autores masculinos que tentaram se colocar no lugar das mulheres de sua época e compreender sua situação em uma sociedade patriarcal, tornando-se porta-vozes de seu sofrimento e de suas reivindicações. Acreditamos que Choderlos de Laclos foi um desses homens, que deixou evidente sua proposta de transformação não apenas política e econômica, mas social, por meio de uma revolução no papel das mulheres, que haviam se tornado, em suas palavras, escravas dos homens. Vale lembrar que entre os séculos XVII e XIX, a literatura francesa escrita por mulheres vivia a sua fase feminina, durante a qual era privilegiada uma “[...] imitação e internalização dos valores e padrões vigentes" (ZOLIN, 2009, p. 330).

Ou seja, enquanto as escritoras Madame de Lafayette e George Sand ainda traziam personagens femininas buscando se adequar às regras sociais, Laclos já apresentava uma 
mulher questionadora das regras impostas ao seu sexo. Isso porque a voz feminina/feminista que ecoa através dos séculos, desde pelo menos a Medeia de Eurípedes, é tão potente e verdadeira que, muitas vezes, não pode deixar de utilizar a voz dos próprios homens para se fazer ouvir. E ambos os sexos se tornam, assim, complementares e cúmplices, ainda que de modo inconsciente, no reconhecimento das palavras escritas por mulheres.

\section{Referências}

BENVENISTE, Émile. Problèmes de linguistique générale I. Paris: Gallimard, 2000.

CALAS, Frédéric. Le roman épistolaire. Paris: Armand Colin, 2007.

COULET, Henri. Le roman jusqu'à la révolution: histoire du roman en France . 2. ed. Paris: Librairie Armand Colin, 1968. Tome I.

DELON, Michel. P.-A. Choderlos de Laclos: Les liaisons dangereuses. 2. ed. Paris: Presses Universitaires de France, 1990.

GENETTE, Gérard. Discours du récit: essai de méthode. Éditions du Seuil: Paris, 2007.

HORÁCIO. Arte poética. In: ARISTÓTELES, HORÁCIO, LONGINO. A poética clássica. Tradução Jaime Bruna. São Paulo: Editora Cultrix, 2005. p. 55-68.

HUMBERT, Brigitte E. De la lettre à l'écran: Les liaisons dangereuses. Amsterdam, Atlanta: Éditions Rodopi, 2000.

LACLOS, Choderlos de. OEuvres complètes. Paris: Gallimard, 2007.

MALRAUX, André. Préface. In: LACLOS, Choderlos de. Les liaisons dangereuses. Paris: Gallimard, 2007. p. 7-22.

MAY, Georges. Le dilemme du roman au XVIIIe siècle. Paris: Presses Universitaires de France, 1963.

POMEAU, René. Laclos ou le paradoxe. Paris: Hachette, 1993.

ROUANET, Sérgio Paulo. O desejo libertino entre o iluminismo e o contra-iluminismo. In: NOVAES, Adauto (Org.). O desejo. São Paulo: Companhia das Letras, 1990. p. 167-196.

ROUSSET, Jean. Forme et signification: essais sur les structures littéraires de Corneille à Claudel. Paris: Librairie José Corti, 1962.

SEYLAZ, Jean-Luc. Les liaisons dangereuses et la création romanesque chez Laclos. Paris: Droz, 1998.

TERZAKIS, P. G. As ligações perigosas na literatura e no cinema: ponto de vista e construção de sentidos. 2013. 171 f. Tese (Doutorado em Letras) - Universidade Federal da Paraíba, João Pessoa, 2013. 
TOMACHEVSKI, B. Temática. In: EIKHENBAUM, Boris et al. Teoria da literatura: formalistas russos. Tradução Ana Mariza Ribeiro Filipouski et al. Porto Alegre: Editora Globo, 1973, p. 169-204.

VAILLAND, Roger. Laclos. Paris: Éditions du Seuil, 1953. (Collection Écrivains de toujours).

VERSINI, Laurent. Le roman le plus intelligent: Les liaisons dangereuses de Laclos. Paris: Honoré Champion Éditeur, 1998.

ZOLIN, Lúcia Osana. Literatura de autoria feminina. In: BONNICI, Thomas; ZOLIN, Lúcia Osana (org.). Teoria literária: abordagens históricas e tendências contemporâneas. 3. ed. Maringá: Eduem, 2009. p. 327-336.

Recebido em 07/08/2018 Aceito para publicação em 05/12/2018 